\title{
Halina Nakonieczna-Kisiel*
}

Uniwersytet Szczeciński

\section{ROLA USŁUG W GOSPODARCE PO WEJŚCIU POLSKI DO UNII EUROPEJSKIEJ}

\section{Streszczenie}

Celem opracowania jest identyfikacja znaczenia sektora III w gospodarce Polski po wejściu do UE. Z badań wynika, że rola tego sektora zmalała w tworzeniu WDB oraz nakładach inwestycyjnych ogółem, zwiększyła się natomiast w powstawaniu nowych miejsc pracy i ograniczaniu deficytu na rachunku obrotów bieżących. Do zmniejszenia roli usług w wymienionych strukturach gospodarki przyczyniał się głównie dominujący udział tradycyjnych sekcji usługowych mało wydajnych i zatrudniających osoby o niskich kwalifikacjach. Wzrost znaczenia usług w poprawie równowagi zewnętrznej wynikał z kolei z rozszerzenia transakcji zaliczanych do usług oraz oddziaływania narzędzi integrujących unijny rynek usług.

Słowa kluczowe: Polska, serwicyzacja, tradycyjne sekcje usługowe, nowoczesne sekcje usługowe

\footnotetext{
*Adres e-mail: hakisiel@wp.pl.
} 


\section{Wprowadzenie}

We współczesnej gospodarce charakterystycznym zjawiskiem jest rozwój serwicyzacji, czyli wzrostu udziału usług w strukturach gospodarek większości krajów świata. Proces ten determinuje szereg czynników. Najważniejszym jest wzrost realnego dochodu per capita, który powoduje przesuwanie popytu konsumpcyjnego z dóbr podstawowych i przemysłowych na usługi, ponieważ lepiej zaspakajają potrzeby. Rośnie też społeczne zapotrzebowanie na droższe produkty przemysłowe o wysokiej jakości (z grupy tzw. wysokiej techniki), którą zapewnia w znacznym zakresie wartość dodana pochodząca ze świadczonych usług. Przykładowo w 2011 roku średnio ponad 25\% nakładów pośrednich (na $\mathrm{B}+\mathrm{R}$, projektowanie, marketing, telekomunikację itd.) zakupionych przez producentów w USA pochodziło z sektora usług (Chilimoniuk-Przeździecka, Kuźnar, 2016, s. 143). Nie bez znaczenia dla rozwoju serwicyzacji był również fakt, że usługi przyczyniają się do poprawy standardu życia, zwiększenia szeroko pojętego bezpieczeństwa oraz wzrostu konkurencyjności gospodarki (Ustugi w Polsce..., 2008, s. 5; Kuczewska, 2007, s. 131; Zielińska-Głębocka, 2012, s. 95).

Celem artykułu jest przedstawienie roli usług w gospodarce Polski po wejściu do UE. Rolę tę zidentyfikowano za pomocą następujących mierników (wskaźników):

- udział usług w wartości dodanej brutto (produkcie krajowym brutto minus podatki i subwencje),

- udział usług w liczbie pracujących ogółem,

- udział usług w nakładach inwestycyjnych ogółem,

- udział usług w bilansie płatniczym.

Wybór wskaźników zdeterminowały ograniczone ramy opracowania. Ich oceny dokonano w odniesieniu do roli usług notowanej w okresie przedakcesyjnym ${ }^{1}$. Pozwoliło to dodatkowo zweryfikować wpływ uczestnictwa Polski w strukturach unijnych na rozwój krajowego sektora usług i na zmiany jego roli w gospodarce. Okres badawczy obejmuje lata 2000-2015, a bazą danych są źródła GUS i NBP. Jako metody badawcze wykorzystano studia literatury przedmiotu, metody statystyczne (dynamiki i struktury) oraz metodę opisową i porównawczą.

\footnotetext{
1 Jeżeli nie zaznaczono inaczej, to okres ten obejmuje lata 2000-2003.
} 


\section{Udział w wartości dodanej brutto}

W latach 2004-2015 wartość dodana brutto (WDB) w usługach (sektor III) wzrosła o około 93\%, podczas gdy w sektorze II (przemysł i budownictwo) o 101\%, a w sektorze I (rolnictwo, leśnictwo, łowiectwo i rybactwo) tylko o 36\% (por. tab. 1). W badanych latach przedakcesyjnych przyrost WDB w usługach był wyraźnie mniejszy, bo zaledwie $12 \%$, jednak wyższy niż w sektorze II (7,9\%), natomiast w sektorze I odnotowano wręcz jej spadek (o 5,5\%). Wskazuje to, że po wejściu Polski do UE nastąpiło odwrócenie tendencji występujących w okresie przed członkowskim, w którym dynamika usług była wyższa niż przemysłu i budownictwa.

Tempo zmian sektorowych po 2004 roku znalazło odzwierciedlenie w zmniejszeniu roli usług w tworzeniu WDB. Na koniec 2015 roku sektor III tworzył wprawdzie około 63\% WDB, jednak w porównaniu z okresem przedakcesyjnym jego odsetek był o 1-3 p.p. mniejszy, natomiast sektora II o 2-3 p.p. większy (por. tab. 1).

Tabela 1. Wartość dodana brutto i jej struktura według sektorów gospodarki ${ }^{a}$

\begin{tabular}{|c|c|c|c|c|c|c|c|}
\hline \multirow{2}{*}{ Lata } & $\begin{array}{c}\text { Ogółem } \\
\text { w gospodarce }\end{array}$ & \multicolumn{2}{|c|}{ Sektor I $^{\mathrm{b}}$} & \multicolumn{2}{c|}{ Sektor II $^{\mathrm{c}}$} & \multicolumn{2}{c|}{ Sektor III $^{\mathrm{d}}$} \\
\cline { 2 - 8 } & $\mathrm{mln} \mathrm{zł}$ & $\mathrm{mln} \mathrm{zł}$ & $\%$ & $\mathrm{mln} \mathrm{zl}$ & $\%$ & $\mathrm{mln} \mathrm{zl}$ & $\%$ \\
\hline 2000 & 662871 & 23113 & 3,5 & 215768 & 32,5 & 423990 & 64,0 \\
\hline 2001 & 693246 & 25122 & 3,5 & 214309 & 30,9 & 453815 & 65,5 \\
\hline 2002 & 714969 & 21839 & 3,1 & 216631 & 30,3 & 476499 & 66,6 \\
\hline 2003 & 745215 & 21836 & 2,9 & 232841 & 31,2 & 490538 & 65,8 \\
\hline 2004 & 825345 & 30479 & 3,7 & 270306 & 32,7 & 524560 & 63,6 \\
\hline 2005 & 870349 & 28703 & 3,3 & 285507 & 32,8 & 556139 & 63,9 \\
\hline 2006 & 973627 & 28558 & 3,0 & 310549 & 33,1 & 598520 & 63,8 \\
\hline 2007 & 1036486 & 35705 & 3,4 & 344059 & 33,2 & 656772 & 63,4 \\
\hline 2008 & 1123819 & 32614 & 2,9 & 374348 & 33,3 & 716857 & 63,8 \\
\hline 2009 & 1220098 & 34101 & 2,8 & 408995 & 33,5 & 777002 & 63,7 \\
\hline 2010 & 1271475 & 37085 & 2,9 & 421694 & 33,2 & 812696 & 63,9 \\
\hline 2011 & 1376956 & 44371 & 3,2 & 467421 & 33,9 & 865164 & 62,8 \\
\hline 2012 & 1443624 & 43413 & 3,0 & 484646 & 33,6 & 915565 & 63,4 \\
\hline 2013 & 1470864 & 47618 & 3,2 & 474236 & 32,2 & 949010 & 64,5 \\
\hline 2014 & 1524940 & 44939 & 2,9 & 506332 & 32,2 & 973669 & 63,8 \\
\hline 2015 & 1595276 & 41514 & 2,6 & 543674 & 34,1 & 1010088 & 63,3 \\
\hline
\end{tabular}

${ }^{\mathrm{a}}$ Ceny bieżące, ${ }^{\mathrm{b}}$ rolnictwo, leśnictwo, łowiectwo i rybactwo, ${ }^{\mathrm{c}}$ przemysł i budownictwo, ${ }^{\mathrm{d}}$ usługi.

Źródło: obliczenia własne na podstawie Rocznik Statystyczny Rzeczypospolitej Polskiej (za odpowiednie lata). 
Zjawisko spadku roli usług w rozwoju gospodarczym ma charakter ogólnoświatowy. Jego przyczynami były, z jednej strony, wybuch kryzysu finansowego i związane z nim ograniczenie roli sektora usług bankowych (wcześniej nadmiernie rozbudowywanego) oraz rosnący popyt na surowce i żywność, który spowodował wzrost cen i produkcji dóbr podstawowych, a zatem i przemysłu w światowym produkcie brutto ${ }^{2}$. Z drugiej natomiast - wzrost udziału produkcji przemysłowej w produkcie globalnym wynikał - jak wcześniej sygnalizowano - z rosnącej absorpcji usług w procesie produkcji dóbr, zwłaszcza zaawansowanych technologicznie. Zjawisko to zdaniem niektórych badaczy będzie miało charakter trwały, gdyż sektor usług jest wręcz uzależniony od przemysłu (Chilimoniuk-Przeździecka, Kuźnar, s. 142). W Europie proces reindustrializacji został również zdeterminowany rosnącą współzależnością usług i produkcji przemysłowej, a ponadto relatywnie lepszymi wynikami krajów silniej uprzemysłowionych (np. Niemiec) w czasie wybuchu kryzysu finansowego w porównaniu z krajami mniej uprzemysłowionymi oraz tymi, w których był rozbudowywany sektor bankowy (Reindustrializacja Europy...). W 2010 roku Komisja Europejska opracowała więc nową strategię rozwoju gospodarki opartej na wiedzy. Promuje ona rozwój nowoczesnego przemysłu oraz nowoczesnych usług, charakteryzujących się wysoką wydajnością i dużym udziałem kapitału ludzkiego o wysokich kwalifikacjach ${ }^{3}$. Wówczas usługi takie, jak projektowanie, B+R, inżynieryjne itp., zwiększać będą wartość produkowanych dóbr, a zatem $i$ ich udział w PKB.

Tymczasem w Polsce strukturę WDB w usługach zdominowały sekcje tradycyjne. W 2000 roku ich udział wynosił ponad 45\%, przy czym najwięcej, bo ponad $32 \%$, przypadało na handel i naprawy, transport i gospodarkę magazynową oraz na administrację publiczną i obronę narodową, natomiast na nowoczesne sekcje (obsługa nieruchomości oraz działalność finansowa i ubezpieczenia) zaledwie 18\% (por. tab. 2).

Po wejściu Polski do UE, mimo iż pojawiły się nowe sekcje usług o nowoczesnym charakterze, nienotowane w latach poprzednich, tj. informacja i komunikacja oraz działalność profesjonalna, naukowa i techniczna, to i tak udział usług nowoczesnych w strukturze WDB sektora III zwiększył się w 2015 roku tylko o 1 p.p. (do około 19\%), zaś tradycyjnych zmniejszył również o 1 p.p. (do 44\%).

\footnotetext{
2 Szerzej na ten temat zob. m.in. Dudziński, Narękiewicz (2016).

${ }^{3}$ Szerzej na ten temat zob. m.in. Strategia Europa 2020...; Wróbel (2014).
} 
Tabela 2. Struktura WDB w sektorze usługowym według sekcji (\%)

\begin{tabular}{|c|c|c|c|c|c|}
\hline \multirow{2}{*}{ Sekcja } & \multicolumn{5}{|c|}{ Lata } \\
\hline & 2000 & 2004 & 2010 & 2014 & 2015 \\
\hline 1. Handel i naprawy pojazdów samochodowych & 19,5 & 18,9 & 19,3 & 17,8 & 17,6 \\
\hline 2. Transport gospodarka magazynowa & 6,6 & 7,2 & 5,3 & 6,3 & 6,3 \\
\hline 3. Zakwaterowanie i gastronomia & 1,3 & 1,1 & 1,2 & 1,2 & 1,2 \\
\hline 4. Informacja i komunikacja & - & - & 3,9 & 3,9 & 4,1 \\
\hline 5. Działalność finansowa i ubezpieczeniowa & 5,0 & 4,0 & 4,1 & 4,5 & 4,0 \\
\hline 6. Obsługa rynku nieruchomości & 13,1 & 13,5 & 5,3 & 5,2 & 5,3 \\
\hline 7. Działalność profesjonalna, naukowa i techniczna & - & - & 5,2 & 5,5 & 5,8 \\
\hline 8. Administrowanie i działalność wspierająca & - & - & 1,8 & 2,1 & 2,2 \\
\hline $\begin{array}{l}\text { 9. Administracja publiczna i obrona narodowa, } \\
\text { obowiązkowe zabezpieczenia społeczne }\end{array}$ & 6,1 & 6,1 & 6,1 & 5,7 & 5,5 \\
\hline 10.Edukacja & 4,4 & 5,1 & 5,1 & 4,8 & 4,8 \\
\hline 11. Opieka zdrowotna i pomoc społeczna & 3,3 & 3,6 & 4,3 & 4,5 & 4,3 \\
\hline $\begin{array}{l}\text { 12.Działalność związana z kulturą, rozrywką } \\
\text { i rekreacją }^{\mathrm{a}}\end{array}$ & 3,7 & $3,8^{\mathrm{a}}$ & 0,9 & 0,7 & 0,7 \\
\hline $\begin{array}{l}\text { 13. Pozostała działalność usługowa (łącznie z działalno- } \\
\text { ścią gospodarstw domowych na potrzeby własne) }\end{array}$ & 0,6 & 0,6 & 1,4 & 1,6 & 1,5 \\
\hline Ogółem usługi & 63,6 & 63,9 & 63,9 & 63,8 & 63,3 \\
\hline
\end{tabular}

a W latach 2000-2003 sekcja ta nazywała się „,działalność komunalna, społeczna i indywidualna pozostała”.

Źródło: jak pod tab. 1.

Występowaniem tego ostatniego zjawiska można zatem wyjaśnić relatywnie mały spadek w Polsce roli sektora III w tworzeniu WDB. Tradycyjne usługi nie współuczestniczą bowiem w takim zakresie, jak nowoczesne, w procesach produkcji dóbr przemysłowych.

\section{Udział w tworzeniu miejsc pracy}

Rola usług w gospodarce przejawia się także w tworzeniu miejsc pracy. W latach 2004-2015 sektor III był w Polsce największym pracodawcą, bowiem liczba osób zatrudnionych wzrosła w nim o blisko $24 \%$, podczas gdy w sektorze I i II odpowiednio tylko o 11 i $9 \%$ (por. tab. 3). Był to niewielki przyrost liczby pracujących, tym niemniej zasługuje na podkreślenie, gdyż w okresie przed członkowskim liczba 
pracujących w usługach wykazywała tendencję spadkową. W 2003 roku w porównaniu z rokiem 2000 zatrudnienie w usługach zmniejszyło się bowiem o 3,1\%, podczas gdy w sektorze II o $11,6 \%$, a w sektorze I aż o ponad $50 \%$. Wynikało to $\mathrm{z}$ bankructwa wielu przedsiębiorstw przemysłowo-budowlanych oraz niemal całkowitej likwidacji PGR. Usługi w takich warunkach pełniły zatem rolę katalizatora skutków restrukturyzacji gospodarki, absorbując pracowników tracących pracę (Słomińska, 2008, s. 44).

Odzwierciedleniem wzrostu liczby zatrudnionych w usługach po przejściu Polski do UE jest wzrost udziału tego sektora w ogólnej liczbie pracujących w gospodarce. W latach 2004-2015 odsetek ten zwiększył się o 2,5 p.p. (do 58\%), zaś w porównaniu z poziomem tego wskaźnika w latach 2000-2002 aż w granicach 11-17 p.p. (por. tab. 3).

Tabela 3. Liczba i struktura pracujących według sektorów (tys.)

\begin{tabular}{|c|c|c|c|c|c|c|c|}
\hline \multirow{2}{*}{ Lata } & $\begin{array}{c}\text { Ogółem } \\
\text { w gospodarce }\end{array}$ & \multicolumn{2}{|c|}{ Sektor I } & \multicolumn{2}{c|}{ Sektor II } & \multicolumn{2}{c|}{ Sektor III } \\
\cline { 2 - 7 } & tys. & tys. & $\%$ & tys. & $\%$ & tys. & $\%$ \\
\hline 2000 & 15489 & 4305 & 27,8 & 3949 & 25,5 & 7235 & 46,7 \\
\hline 2001 & 14996 & 4290 & 28,6 & 3701 & 24,7 & 7005 & 46,7 \\
\hline 2002 & 14924 & 4282 & 28,7 & 4565 & 30,6 & 6077 & 40,7 \\
\hline 2003 & 12641 & 2138 & 16,9 & 3489 & 27,6 & 7014 & 55,5 \\
\hline 2004 & 12720 & 2140 & 16,8 & 3520 & 27,7 & 7060 & 55,5 \\
\hline 2005 & 12891 & 2134 & 16,6 & 3519 & 27,3 & 7238 & 56,1 \\
\hline 2006 & 13220 & 2135 & 16,1 & 3685 & 27,9 & 7400 & 56,0 \\
\hline 2007 & 13771 & 2138 & 15,5 & 3908 & 28,4 & 7725 & 56,1 \\
\hline 2008 & 14037 & 2128 & 15,1 & 3938 & 28,1 & 7971 & 56,8 \\
\hline 2009 & 13782 & 2125 & 15,4 & 3775 & 27,4 & 7882 & 57,2 \\
\hline 2010 & 14107 & 2376 & 16,8 & 3775 & 26,8 & 7956 & 56,4 \\
\hline 2011 & 14233 & 2377 & 16,7 & 3825 & 26,8 & 8032 & 56,4 \\
\hline 2012 & 14172 & 2378 & 16,8 & 3735 & 26,4 & 8059 & 56,9 \\
\hline 2013 & 14244 & 2379 & 16,7 & 3683 & 25,9 & 8182 & 57,4 \\
\hline 2014 & 14563 & 2385 & 16,4 & 3776 & 25,9 & 8402 & 57,7 \\
\hline 2015 & 14830 & 2385 & 16,1 & 3844 & 25,9 & 8601 & 58,0 \\
\hline
\end{tabular}

Źródło: jak pod tab. 1.

Najwięcej miejsc pracy w sektorze III tworzyły znów sekcje tradycyjne, czyli głównie handel i naprawy, a w mniejszym stopniu opieka zdrowotna, edukacja, 
administracja publiczna i obrona narodowa oraz transport i magazynowanie. W 2000 roku ich udział w ogólnej liczbie pracujących w tym sektorze wynosił ponad 35\%, natomiast na koniec 2015 roku zwiększył się aż o 12 p.p. (por. tab. 4). Przyrost miejsc pracy wynikał z dokonujących się przekształceń ustrojowych, z rozwoju przedsiębiorczości w nowych warunkach gospodarowania, z podejmowania pracy na własny rachunek, z rozwoju szkół prywatnych oraz wejścia Polski do Unii Europejskiej. Transfery ze wspólnego budżetu finansowały bowiem szereg przedsięwzięć inwestycyjnych (będzie o nich mowa dalej), którym towarzyszyło zwiększenie nowych miejsc pracy.

Tabela 4. Struktura pracujących w sektorze usługowym według sekcji (\%)

\begin{tabular}{|l|c|c|c|c|r|}
\hline \multirow{2}{*}{ Sekcja } & \multicolumn{5}{c|}{ Lata } \\
\cline { 2 - 6 } & 2000 & 2004 & 2010 & 2014 & 2015 \\
\hline 1. Handel i naprawy & 13,4 & 15,6 & 15,5 & 14,9 & 15,0 \\
\hline 2. Transport i gospodarka magazynowa & 5,0 & 5,5 & 5,0 & 5,1 & 5,2 \\
\hline 3. Zakwaterowanie i gastronomia & 1,5 & 1,7 & 1,7 & 1,7 & 1,7 \\
\hline 4. Informacja i komunikacja & - & - & 1,7 & 2,0 & 2,1 \\
\hline 5. Działalność finansowa i ubezpieczeniowa & 1,9 & 2,2 & 2,4 & 2,5 & 2,4 \\
\hline 6. Obsługa nieruchomości & 5,3 & 7,4 & 1,4 & 1,4 & 1,4 \\
\hline 7. Działalność profesjonalna, naukowa, techniczna & - & - & 3,4 & 4,0 & 4,1 \\
\hline 8. Administrowanie i działalność wspierająca & - & - & 2,9 & 3,2 & 3,4 \\
\hline 9. Administracja publiczna i obrona narodowa & 5,3 & 6,7 & 6,9 & 6,7 & 6,5 \\
\hline 10. Edukacja & 5,8 & 7,9 & 7,7 & 7,7 & 7,7 \\
\hline 11. Opieka zdrowotna i pomoc społeczna & 5,9 & 5,5 & 5,4 & 5,7 & 5,7 \\
\hline 12. Działalność związana z kulturą, rozrywką i rekreacją & 2,5 & 3,0 & 1,1 & 1,0 & 1,0 \\
\hline 13. Pozostała działalność usługowa & - & - & 1,4 & 1,8 & 1,8 \\
\hline Ogółem usługi & 46,6 & 55,5 & 56,5 & 57,7 & 58,0 \\
\hline
\end{tabular}

Źródło: jak pod tab. 1.

Sekcje nowoczesne nie odgrywały większej roli w tworzeniu miejsc pracy w sektorze III. Jednak ich udział w 2015 roku w porównaniu z rokiem 2000 wzrósł o 3 p.p. (do 10\%). Wdrażanie wytycznych Strategii Europa 2020, czyli budowa gospodarki opartej na wiedzy, zwiększało zapotrzebowanie na nowe miejsca pracy głównie dla pracowników obsługujących nowoczesne technologie. Proces ten w Polsce daleki jest jednak od pełnego zaspokojenia potrzeb w tym zakresie ze względu na dominujący wciąż udział tradycyjnych sekcji w tworzeniu miejsc pracy. 


\section{Udział w nakładach inwestycyjnych}

Oprócz zasobów pracy, możliwości rozwoju każdej dziedziny gospodarowania w znacznie większym stopniu zwiększają nakłady inwestycyjne. Pod tym względem sektor usług w Polsce był w szczególnie niekorzystnej sytuacji w okresie przedakcesyjnym. Wartość nakładów inwestycyjnych zmniejszyła się wówczas o 24\%, czyli w stopniu większym niż w sektorze I i II, a nawet w gospodarce ogółem, gdzie odnotowane spadki wynosiły odpowiednio 10, 4 i 17\% (por. tab. 5).

Tabela 5. Nakłady inwestycyjne w Polsce według sektorów gospodarki

\begin{tabular}{|c|c|c|c|c|c|c|c|}
\hline \multirow{2}{*}{ Lata } & $\begin{array}{c}\text { Ogółem } \\
\text { w gospodarce }\end{array}$ & \multicolumn{2}{|c|}{ Sektor I } & \multicolumn{2}{c|}{ Sektor II } & \multicolumn{2}{c|}{ Sektor III } \\
\cline { 2 - 8 } & mln zł & mln zł & $\%$ & mln zł & $\%$ & mln zł & $\%$ \\
\hline 2000 & 131160 & 2483 & 1,9 & 47789 & 35,9 & 82888 & 62,2 \\
\hline 2001 & 121132 & 2281 & 1,9 & 44232 & 36,5 & 74619 & 61,6 \\
\hline 2002 & 109071 & 2263 & 2,1 & 42673 & 39,1 & 64135 & 58,8 \\
\hline 2003 & 110860 & 2232 & 2,0 & 45975 & 41,5 & 62653 & 56,5 \\
\hline 2004 & 120467 & 2627 & 2,2 & 50987 & 42,3 & 66853 & 55,5 \\
\hline 2005 & 131055 & 2980 & 2,3 & 50982 & 38,9 & 77093 & 58,8 \\
\hline 2006 & 154880 & 3427 & 2,2 & 67910 & 43,8 & 83543 & 53,9 \\
\hline 2007 & 191714 & 4118 & 2,1 & 83924 & 43,8 & 103672 & 54,1 \\
\hline 2008 & 217260 & 4600 & 2,1 & 96772 & 44,5 & 115888 & 53,3 \\
\hline 2009 & 218581 & 4094 & 1,9 & 80128 & 36,6 & 134359 & 61,5 \\
\hline 2010 & 217287 & 4282 & 2,0 & 76264 & 35,1 & 136741 & 62,9 \\
\hline 2011 & 243346 & 5334 & 2,2 & 86351 & 35,5 & 151661 & 62,3 \\
\hline 2012 & 237627 & 5730 & 2,4 & 83208 & 35,0 & 148689 & 62,6 \\
\hline 2013 & 231155 & 6080 & 2,6 & 86464 & 37,4 & 138611 & 60,0 \\
\hline 2014 & 250776 & 6155 & 2,5 & 98923 & 39,4 & 145698 & 58,1 \\
\hline 2015 & 271836 & 6084 & 2,2 & 113351 & 41,7 & 152401 & 56,1 \\
\hline
\end{tabular}

Źródło: jak pod tab. 1.

Po wejściu Polski na rynek unijny wartość nakładów inwestycyjnych w usługach podwoiła się w 2015 roku, podobnie zresztą jak i w pozostałych sektorach. Przyczynami tego zjawiska było znaczne przyśpieszenie wzrostu gospodarczego, zwiększony napływ środków z funduszy strukturalnych (szczególnie w latach 2007-2013) oraz zwiększone zainteresowanie podmiotów z kapitałem zagranicznym (pochodzących głównie z krajów UE) inwestowaniem głównie w sektorze 
III (Kłosiewicz-Górecka, 2016, s. 101-116). Przedstawione tendencje w dynamice nakładów inwestycyjnych nie sprzyjały jednak wzrostowi roli usług w strukturze nakładów inwestycyjnych ogółem. W 2015 roku ich udział w gospodarce wynosił około 56\% i był w granicach 2-6 p.p. niższy w latach 2000-2002 (por. tab. 5).

Udziały poszczególnych sekcji w nakładach inwestycyjnych sektora III ponownie zdominowały sekcje tradycyjne, wśród których najwyższe udziały wykazywały w 2000 roku transport i gospodarka magazynowa oraz handel i naprawa pojazdów. Łącznie przypadało na te dwie sekcje blisko 24\%. Jednak udział dwóch nowoczesnych sekcji, czyli działalności finansowej i ubezpieczeń oraz obsługi nieruchomości był od wymienionych tradycyjnych sekcji wyższy o około 2 p.p. (por. tab. 6).

Tabela 6. Struktura nakładów inwestycyjnych w sektorze usługowym według sekcji (\%)

\begin{tabular}{|l|r|r|r|r|r|}
\hline \multirow{2}{*}{ Sekcja } & \multicolumn{5}{c|}{ Lata } \\
\cline { 2 - 6 } & 2000 & 2004 & 2010 & 2014 & 2015 \\
\hline 1. Handel i naprawy & 10,7 & 9,9 & 7,7 & 7,0 & 6,7 \\
\hline 2. Transport i gospodarka magazynowa & 12,8 & 9,5 & 19,7 & 16,8 & 17,6 \\
\hline 3. Zakwaterowanie i gastronomia & 1,2 & 0,9 & 1,1 & 1,0 & 0,9 \\
\hline 4. Informacja i komunikacja & - & - & 3,2 & 2,8 & 2,9 \\
\hline 5. Działalność finansowa i ubezpieczeniowa & 6,6 & 2,9 & 1,9 & 1,8 & 1,5 \\
\hline 6. Obsługa nieruchomości & 19,7 & 19,0 & 12,4 & 13,1 & 11,6 \\
\hline 7. Działalność profesjonalna, naukowa, techniczna & - & - & 1,7 & 2,0 & 1,9 \\
\hline 8. Administrowanie i działalność wspierająca & - & - & 1,3 & 1,8 & 1,9 \\
\hline 9. Administracja publiczna i obrona narodowa & 2,2 & 3,3 & 2,9 & 3,5 & 3,4 \\
\hline 10. Edukacja & 2,6 & 3,1 & 3,6 & 2,7 & 2,7 \\
\hline 11. Opieka zdrowotna i pomoc społeczna & 2,1 & 1,9 & 3,1 & 2,5 & 2,5 \\
\hline 12. Działalność związana z kulturą, rozrywką i rekreacją & 4,3 & 5,0 & 3,9 & 2,7 & 2,1 \\
\hline 13. Pozostała działalność usługowa & - & - & 0,4 & 0,4 & 0,3 \\
\hline Ogółem usługi & 62,2 & 55,5 & 62,9 & 58,1 & 56,1 \\
\hline
\end{tabular}

Źródło: jak pod tab. 1.

Po wejściu Polski w struktury unijne inwestowanie w sekcje tradycyjne uległo zwiększeniu (głównie w transport i gospodarkę magazynową oraz administrację publiczną i obronę), natomiast w nowoczesne zmniejszeniu. Zjawisko to jest bardzo niekorzystne dla gospodarki, gdyż opóźnia modernizację sektora III, a tym samym rozwój gospodarki opartej na wiedzy, co pogarsza pozycję Polski na tle krajów unijnych. 


\section{Udział w bilansie płatniczym}

Rolę usług w bilansie płatniczym należy rozpatrywać przede wszystkim z punktu widzenia ich wpływu na równowagę zewnętrzną kraju, o której świadczy saldo na rachunku bieżącym (Sawicki, 2016, s. 102-107). W latach 2000-2003 Polska osiągała ujemne saldo w obrotach bieżących, jednak wykazywało ono tendencję malejącą. Do prawie dwukrotnego zmniejszenia deficytu na rachunku bieżącym przyczyniły się dodatnie salda transferów bieżących oraz usług. W tych pierwszych w 2003 roku nadwyżka wpłat nad wypłatami zwiększyła się jednak prawie 2 razy, natomiast $\mathrm{w}$ obrotach usługami była dodatnia, ale aż blisko 6 razy mniejsza niż w 2000 roku (por. tab. 7).

Tabela 7. Główne pozycje rachunku obrotów bieżących w latach 2000-2015

\begin{tabular}{|c|c|c|c|c|c|c|c|}
\hline \multirow{3}{*}{ Lata } & \multicolumn{7}{|c|}{ Saldo } \\
\hline & \multirow{2}{*}{$\begin{array}{l}\text { rachunku } \\
\text { bieżącego }\end{array}$} & \multirow{2}{*}{ towarów } & \multirow{2}{*}{ usług } & \multirow{2}{*}{ dochodów } & \multirow{2}{*}{$\begin{array}{l}\text { transakcji } \\
\text { bieżących }\end{array}$} & \multicolumn{2}{|c|}{ dochodów } \\
\hline & & & & & & pierwotnych & wtórnych \\
\hline 2000 & -10343 & -12307 & 1403 & -731 & 1232 & - & - \\
\hline 2002 & -5544 & -7249 & 775 & -1061 & 1991 & - & - \\
\hline 2003 & -5473 & -5725 & 243 & -2461 & 2470 & - & - \\
\hline 2004 & -13830 & -8219 & 1732 & - & - & -8057 & 714 \\
\hline 2008 & -35811 & -34429 & 7374 & - & - & -10157 & 1403 \\
\hline 2010 & -25875 & -14498 & 4364 & - & - & -15623 & 118 \\
\hline 2012 & -18606 & -10495 & 7716 & - & - & -15626 & -200 \\
\hline 2014 & -11444 & -4291 & 12046 & - & - & -18646 & -16559 \\
\hline 2015 & -2932 & 2464 & 12113 & - & - & -500 & -950 \\
\hline
\end{tabular}

Źródło: zestawiono dla lat 2000-2003 według BPM5, dla lat 2004-2015 według BPM6, www.nbp.pl (15.12.2016).

Od 2004 roku zestawianie transakcji w bilansie dokonuje się według nowej metodologii (BPM6). Do obrotów towarowych nie zalicza się uszlachetniania towarów i napraw, wlicza natomiast pośrednictwo handlowe. Usługi zostały pomniejszone o pośrednictwo handlowe, a zwiększone o uszlachetnianie, naprawy i pośrednictwo towarowe. Dochody podzielono na dochody pierwotne i wtórne. Do pierwszych zalicza się wynagrodzenia pracowników i dochody z inwestycji zagranicznych, do drugich (dochodów wtórnych) przekazy zarobków oraz transfery bieżące (rządowe 
oraz prywatne) $)^{4}$. Dane o stanie bilansu obrotów bieżących i wartości jego głównych składowych są więc w latach 2004-2015 nieporównywalne z okresem poprzednio omówionym. Pozwalają jednak na ukazanie tendencji i skali wpływu usług na stan salda obrotów bieżących po wejściu Polski do UE.

W latach 2004-2015, podobnie jak w okresie 2000-2003, rachunek bieżący wykazywał również strukturalny deficyt. Jednak jego ujemne saldo w 2015 roku było prawie 5 razy mniejsze niż w 2004 roku. Do zmniejszenia deficytu w obrotach bieżących przyczyniły się przede wszystkim usługi, gdyż ich niemal systematycznie rosnące przychody przekraczały kwotę wypłat, dając saldo w końcu omawianego okresu aż siedem razy większe niż w 2004 roku. Pozostałe transakcje rachunku bieżącego, czyli obroty towarowe, dochody pierwotne i dochody wtórne na ogół pogłębiały deficyt w obrotach bieżących, gdyż zazwyczaj zamykały się ujemnym saldem (por. tab. 7).

Ukazane przekształcenia w strukturze sald poszczególnych transakcji w obrotach bieżących pozwalają więc stwierdzić, że usługi w obu analizowanych okresach były ważnym elementem równoważenia bilansu płatniczego, ponieważ przyczyniały się do zmniejszenia jego deficytu. Wpływ transakcji usługowych na zmniejszenie ujemnego salda obrotów bieżących był jednak większy w warunkach funkcjonowania Polski w strukturach unijnych niż w okresie nieczłonkowskim. Wynikało to $\mathrm{z}$ jednej strony $\mathrm{z}$ rozszerzenia transakcji zaliczanych do usług, $\mathrm{z}$ drugiej natomiast z oddziaływania instrumentów integracji rynku usług w tym ugrupowaniu, czyli wzajemnego uznawania, harmonizacji i liberalizacji (Szypulewska-Porczyńska, 2012; 2013, s. 61-72). Narzędzia te przyczyniły się do zwiększenia rozmiarów rynku zbytu, powstawania nowych firm nawiązujących współpracę z Polską, co często skutkowało napływem kapitału zagranicznego do sektora III.

\section{Podsumowanie}

Z przeprowadzonych badań wynika, że po wejściu Polski do Unii Europejskiej nastąpiło:

1. Spowolnienie procesu serwicyzacji w polskiej gospodarce, szczególnie widoczne w malejących udziałach sektora III w tworzeniu WDB oraz nakładach inwestycyjnych.

\footnotetext{
${ }^{4}$ Szerzej na ten temat zob. m.in. Nakonieczna-Kisiel, Bilewicz (2016), s. 71-74.
} 
2. Zwiększenie roli usług, głównie w tworzeniu miejsc pracy oraz równoważeniu bilansu płatniczego.

3. Utrzymanie dominacji tradycyjnych sekcji w strukturze sektora usług; spowalniać to może w Polsce proces uprzedmiotowiania usług w dobrach przemysłowych, a co za tym idzie, i reindustrializacji kraju.

4. Zwiększenie znaczenia usług w ograniczeniu nierównowagi zewnętrznej; przyczyniły się do tego zarówno zmiany metodologii zapisywania transakcji w bilansie płatniczym, jak i rozszerzenie narzędzi zwiększających dostęp do unijnego rynku usług.

5. Na przebieg powyższych procesów w sektorze III wpływ UE widoczny był przede wszystkim w tworzeniu miejsc pracy, nakładach inwestycyjnych i bilansie płatniczym. Było to rezultatem głównie napływu z tego obszaru kapitału zagranicznego, funduszy strukturalnych oraz integrowania wewnętrznego rynku usług.

\section{Literatura}

Dudziński, J., Narękiewicz, J. (2016). Chiny a deindustrializacja krajów rozwijających się (na przykładzie Ameryki Łacińskiej). Studia i Prace WNEiZ US, 37 (1).

Chilimoniuk-Przeździecka, E., Kuźnar, A. (2016). Znaczenie usług w globalnych łańcuchach wartości. Gospodarka Narodowa, 5.

Kłosiewicz-Górecka, U. (2016). Nakłady inwestycyjne podmiotów z kapitałem zagranicznym w sektorze usług w Polsce w latach 2010-2014. W: Inwestycje zagraniczne w Polsce 2014-2015. Warszawa: IBR, KiK.

Kuczewska, L. (2007). Sektor usług w strukturze polskiej gospodarki w latach 2000-2005. W: Ustugi w rozwoju społeczno-gospodarczym Unii Europejskiej. Warszawa: IBR, KiK.

Nakonieczna-Kisiel, H., Bilewicz, E. (2016). Nowa metodologia sporządzania bilansu płatniczego. Studia i Prace WNEiZ US, 44 (1).

Reindustrializacja Europy: gospodarka oparta na ustugach byta btędem. Pobrano z: http:// forsal.pl (17.01. 2015).

Rocznik Statystyczny Rzeczypospolitej Polskiej (2001-2016). Warszawa: GUS.

Sawicki, J. (2016).Zmiany stabilności, bilansu płatniczego i międzynarodowej pozycji inwestycyjnej netto w 2015 roku. W: Gospodarka i handel zagraniczny Polski w 2015 roku. Warszawa: IBR, KiK. 
Słomińska, B. (2008). Układ podmiotowy sektora usług oraz udział sekcji usługowych w krajowym rynku pracy. W: Ustugi w Polsce 2000-2007. Warszawa: IBR, KiK.

Strategia Europa 2020. Pobrano z: http://ec.europa.eu//PDF/1 (17.01.2017).

Szypulewska-Porczyńska, A. (2012). Znaczenie zasady wzajemnego uznawania dla integracji usług w Unii Europejskiej. Gospodarka Narodowa, 5-6.

Szypulewska-Porczyńska, A. (2013). Budowa rynku wewnętrznego ustug w Unii Europejskiej. Warszawa: Oficyna Wydawnicza SGH.

Ustugi w Polsce 2002-2007 (2008). Warszawa: IBR, KiK.

Wróbel, A. (2014). Rola sektora usług w rozwoju społeczno-gospodarczym i kształtowaniu gospodarki opartej na wiedzy. Nierówności Społeczne a Wzrost Gospodarczy, 37. Pobrano z: https:/www/ur.edu.pl (17.01.2017).

Zielińska-Głębocka, A. (2012). Wspótczesna gospodarka światowa. Warszawa: Oficyna a Wolters Kluwer business.

\title{
SERVICE ROLE IN ECONOMY AFTER POLAND'S EU ACCESSION
}

\begin{abstract}
The goal of this paper is identification of "third sector" meaning in Polish economy after EU accession. Research results show that this sector role in gross value added creation and total investment has decreased, whereas it has increased in new worksite creation and current account deficit reduction. Decreasing service role in mentioned economic structures was caused mainly by dominant share of traditional, low productive and employing less qualified workers service sections. Then growing importance of services in external balance improvement resulted from service-included transaction enlargement and the influence of EU service market integrating instruments.
\end{abstract}

Translated by Marcin Gryczka

Keywords: Poland, servicization, traditional service sections, modern service sections

JEL codes: E01, E25 
